U posljednjim poglavljima knjige spominju se imena hrvatskih alkemičara Matije Albertija, Filipa Šufflaya, Ivana Nepomuka te baruna Lazara Hellenbacha, koji su se navodno bavili alkemijom, no o čijem djelovanju nema pisanog traga.

Umjesto zaključka, knjiga završava raspravom Gustava Fleischera, profesora iz Bjelovara s kraja 19. stoljeća, koji je prvi u Hrvatskoj pisao o razvitku alkemije, i to poglavito one europske. U raspravi o europskoj alkemiji on alkemiju tumači kao prethodnicu moderne kemije.

Najveću vrijednost ove knjige, nastale kao rezultat arhivskih istraživanja i kritičkog tumačenje tekstova hrvatskih alkemičara, nalazim u tri momenta: ponajprije, u njoj su prvi put sustavno izložene značajke rada hrvatskih alkemičara. Djelovanje tih alkemičara izloženo je kronološkim redom tako da knjiga predstavlja jedan povijesni pregled alkemije $\mathrm{u} \mathrm{Hr}$ vatskoj. Tim su pregledom obuhvaćeni autori koji djeluju od 14. stoljeća sve do najnovijeg doba. Takvog pregleda dosad nismo imali. Do sada, štoviše, uglavnom i nije bilo poznato da su se hrvatski učenjaci bavili alkemijom, tako da ova knjiga i široj javnosti omogućuje upoznavanje s činjenicom da smo i u povijesti europske alkemije imali svoje, u nekim slučajevima i značajne, predstavnike. Osim toga autorica je u knjizi, pored nekih ranije objavljenih, ali slabo poznatih tekstova hrvatskih alkemičara, protumačila i vrednovala i neke još neobjavljene rukopise ili rijetka djela tih alkemičara.

U knjizi su valorizirana djela tih alkemičara $\mathrm{u}$ europskom obzoru, pri čemu je istaknuto značenje koje su neka od tih djela igrala u okviru povijesti europske alkemije. Autorica je pokazala da su istraživanja nekolicine tih alkemičara bila na razini europskih suvremenika. Kao primjer naveden je zbornik alkemijskih tekstova Petra Bona iz 14. st., što ga je objavio Aldo Manuzzi u Veneciji, a bio je preveden na gotovo sve europske jezike. Ukratko, autorica Snježana Paušek-Baždar ovom je knjigom pokušala ukazati na važnost alkemije u povijesti europske znanosti i filozofije, ali i pokazati da su i Hrvati dali znatan doprinos njenom razvoju.

\section{Erna Banić-Pajnić}

doi: $10.21464 /$ fi38419

\section{Maja Miloš, Robert Doričić (ur.)}

\section{Europska bioetika na djelu}

\section{EuroBioAct: lista bioetičkih standarda za lokalnu zajednicu}

\section{Medicinski fakultet Sveučilišta \\ u Rijeci, Dokumentacijsko-istraživački centar za europsku bioetiku »Fritz Jahr« Sveučilišta u Rijeci, Rijeka 2017.}

Knjižica Europska bioetika na djelu - EuroBioAct: lista bioetickkih standarda za lokalnu zajednicu, koju kao urednici potpisuju Robert Doričić i Maja Miloš, tiskana u Rijeci u izdanju Medicinskog fakulteta Sveučilišta u Rijeci i Dokumentacijsko-istraživačkog centra za europsku bioetiku »Fritz Jahr« Sveučilišta u Rijeci, predstavlja sumarni prikaz projekta iz samog naslova. »Eurobioact - Europska bioetika na djelu« ime je projekta kojemu je nositelj bila Katedra za društvene i humanističke znanosti u medicini Medicinskog fakulteta Sveučilišta u Rijeci, a voditelj projekta i glavni istraživač Amir Muzur. Projekt se odvijao od 15. rujna 2014. do 14. rujna 2017. i financiran je od strane Hrvatske zaklade za znanost.

Urednici knjige doktorandi su zaposleni na projektu, a njihov je cilj bio dati kratki, ali informativni sumarni prikaz odvijanja projekta, njegovih istraživačkih i suradničkih nositelja te glavnih rezultata. Prvi dio, naslovljen »O projektu«, donosi opće informacije o projektu, misiju i viziju projekta, predstavlja opći cilj te opisuje ukratko istraživačke faze i pripadnu metodologiju. Opći je cilj formuliran na sljedeći način:

»Opći cilj projekta jest dokazati da teorijski i metodološki pristup 'europske bioetike', odnosno integrativne bioetike, može rezultirati platformom za rješavanje praktičnih problema očuvanja i poboljšanja okoliša. Posljedično, takav način rješavanja problema u zajednici može pozitivno utjecati na razvoj gospodarstva i promociju turizma.« (str. 5)

Ostvarivanje cilja zamišljeno je kroz četiri projektne faze: 1. Produbljivanje teorijske osnove; 2. Analiza stanja u lokalnim zajednicama; 3. Provedba radionica; 4. Kreiranje liste bioetičkih standarda. Korištene su pluriperspektivna metodologija, otvorena metoda koordinacije i načelo opreza.

Drugi dio, »Istraživanje u zajednici; Lokalne zajednice« predstavlja razloge zbog kojih su 
izabrane upravo određene tri lokalne zajednice - Grad Bakar, Općina Kršan i Grad Mali Lošinj. Prvenstveno je obrazloženo na koji je način istraživanje vezano za te tri lokalne zajednice, i to kroz dva ciljana istraživanja koja su ujedno teme doktorskih disertacija samih urednika knjižice. Naposljetku su ukratko predstavljene sve tri zajednice sa svojim specifičnostima koje su ih i odredile kao idealne partnere $u$ istraživanju: Bakar prije svega sa svojom industrijskom prošlošću i njenim posljedicama (s koksarom u prvome redu), Kršan sa svojom industrijskom prošlošću i sadašnjošću (s termoelektranom Plomin u prvome redu) te Mali Lošinj kao okolina lišena prirodnih zagađenja i u punom smislu zdravstveno-lječilišna oaza.

Centralni, treći dio predstavlja bioetičke standarde kao glavni rezultat provedenih istraživanja, a koji su dobiveni gradnjom na teorijskim zasadama »europske bioetike«, s jedne strane, te empirijskoga testiranja $\mathrm{u}$ samim lokalnim zajednicama, s druge strane. Naposljetku je dobivena obuhvatna lista standarda, $\mathrm{i}$ to njih 23 koja se tiču životinja, 20 vezanih uz biljke i $54 \mathrm{u}$ čijem je fokusu interakcija ljudi i okoliša. Osim etičke i bioetičke relevantnosti ove liste standarda u teorijskom smislu, jasno se ističe i njihova praktična upotrebljivost:

»Lokalne vlasti moći će konačnu listu standarda koristiti kao podlogu za strateško promišljanje razvoja i sustavnog podizanja kvalitete života na svom području, ali i kao turističku legitimaciju. Osim toga očekuje se da će stanovništvo dosegnuti dodatnu bioetičku osviještenost koja će onemogućit počinjanje ili izbjeći ponavljanje pogrešaka mnogih sredina.« (str. 17)

U posljednjem je dijelu predstavljena projektna skupina, znanstvene konferencije te publikacije vezane za projekt. Tako je jasno vidljivo da je projektni tim činilo osam iskusnih hrvatskih istraživača u području bioetike, dvoje istaknutih inozemnih istraživača te dvoje istraživača doktoranada. Održane su dvije znanstvene konferencije u sklopu projekta, a urednici donose impresivan popis od čak 28 publikacija vezanih za projekt, od čega čak 3 knjige, te 40 sudjelovanja na skupovima, koja se tiču projekta.

Naposljetku su popisani partneri projekta (Grad Bakar, Općina Kršan i Grad Mali Lošinj), institucije uključene u projekt (Medicinski fakultet Sveučilišta u Rijeci, Fakultet zdravstvenih studija Sveučilišta u Rijeci, UNESCO katedra za društvene i humanističke znanosti Sveučilišta u Rijeci, Dokumentacijsko-istraživački centar za europsku bioetiku »Fritz Jahr« Sveučilišta u Rijeci i Znanstveni centar izvrsnosti za integrativnu bioetiku) te je istaknuta i zahvala na pomoći i suradnji nekolicini drugih subjekata (Nastavni zavod za javno zdravstvo Primorsko-goranske županije, Ured državne uprave u Primorsko-goranskoj županiji - Služba za opću upravu, Ured državne uprave u Primorsko-goranskoj županiji - Matični ured Bakar, Ured državne uprave u Primorsko-goranskoj županiji - Matični ured Mali Lošinj, Turistička zajednica Grada Bakra, Turistička zajednica Općine Kršan, Jadranka d.d. Mali Lošinj).

Ovu je knjižicu moguće vrednovati barem iz tri osnovna ugla: informacijskog, znanstvenog i promidžbenog.

Prvo, njome je na jednome mjestu sumiran višegodišnji rad na jednome bioetičkome projektu, čime su ti podaci na vrlo jasan, pregledan i jednostavan način dostupni drugim istraživačima za korištenje bilo u sadržajnome ili pak metodološkome smislu. Njome su u vrlo praktičnom formatu obuhvaćeni svi najvažniji relevantni podaci o projektu, njegovu sadržaju i provedbi.

Drugo, ona je ujedno mjesto na kojemu su prvi put objavljeni dobiveni bioetički standardi kao glavni rezultat istraživačkog projekta i platforma za daljnju gradnju, modifikaciju i raspravu o istima. Taj je dio vezan uz znanstvenu relevantnost osnovnog rezultata projekta koji je u objedinjenoj formi predstavljen široj publici na ovaj način i dan na daljnju kritičku evaluaciju.

Treće, svi su materijali u punom obliku ujedno dani i na engleskome jeziku te je sama knjižica dizajnerski vješto skrojena (poseban kvadratni format knjige, dizajn korica, grafička i slikovna opremljenost) što ovom dvojezičnom izdanju daje posebnu dimenziju jer na svojih 72 stranice ona predstavlja veličinom vrlo praktičnu i oku vrlo atraktivnu publikaciju kojom se i nositelj i partneri, ali i svi suradnici na projektu mogu dostojno predstavljati kako u zemlji tako i izvan nje.

Kritička evaluacija projekta, iako već dijelom započeta (vidi: Igor Eterović, Robert Doričić, »EuroBioAct: New paths of integrative bioethics«, Nova prisutnost 15 (2017) 3, str. 377-391), tek predstoji, a ova će publikacija omogućiti publici da se to efikasnije i ostvari, što je možda i najznačajnija dimenzija projekta: diseminacija rezultata i ideja projekta $u$ svrhu njihova raspravljanja, produbljivanja i kretanja u nove istraživačke putove bioetike.

\section{Igor Eterović}

